Bull. Chem. Soc. Ethiop. 2013, 27(3), 329-346.

Printed in Ethiopia

DOI: http://dx.doi.org/10.4314/bcse.v27i3.2

ISSN 1011-3924

(c) 2013 Chemical Society of Ethiopia

\title{
KINETIC SPECTROPHOTOMETRIC DETERMINATION OF SOME FLUOROQUINOLONE ANTIBIOTICS IN BULK AND PHARMACEUTICAL PREPARATIONS
}

\author{
Mohammed G. Abdel Wahed, Ragaa El Sheikh, Ayman A. Gouda ${ }^{*}$ and Sayed Abou Taleb \\ Chemistry Department, Faculty of Science, Zagazig University, Zagazig, 44519, Egypt
}

(Received January 18, 2013; revised June 1, 2013)

\begin{abstract}
A simple and sensitive kinetic spectrophotometric method was developed for the determination of some fluoroquinolonea antibiotics; gemifloxacin mesylate, moxifloxacin hydrochloride and gatifloxacin in bulk and in pharmaceutical preparations. The method is based upon a kinetic investigation of the oxidation reaction of the drugs with alkaline potassium permanganate at room temperature for a fixed time of $20 \mathrm{~min}$ for gemifloxacin and $15 \mathrm{~min}$ for moxifloxacin or gatifloxacin. The absorbance of the coloured manganate ion was measured at 610 $\mathrm{nm}$. The absorbance-concentration plots were rectilinear over the ranges of $2.0-20,4.0-24$ and $4.0-40 \mu \mathrm{g} \mathrm{mL}^{-1}$ for gemifloxacin, moxifloxacin and gatifloxacin, respectively. The concentrations of the studied drugs were calculated using the corresponding calibration equations for the fixed-time method. The determination of the studied drugs by the fixed concentration and rate constant methods was also feasible with the calibration equations obtained but the fixed time method has been found to be more applicable. The different experimental parameters affecting the development and stability of the colors were carefully studied and optimized. The proposed method was applied to the determination of the studied drugs in pharmaceutical formulations.
\end{abstract}

KEY WORDS: Kinetic determination, Spectrophotometry, Fluoroquinolone antibiotics, Potassium permanganate, Pharmaceutical preparations

\section{INTRODUCTION}

Fluoroquinolones are the second-generation members of quinolone antibiotics fluorinated in position 6 and bearing a piperazinyl moiety at position. They are considered to be the most effective gram-positive and gram-negative pathogens to combat infection caused by microorganisms that are resistant to other microbials, such as tetracyclines. Also, they have some activity against mycobacteria, mycoplasmas, rickettsias, and the protozoan Plasmodium falcisparm $[1,2]$. There is a substantial body of literature related to both the mechanism of their action as DNA gyrase inhibitors, and the influence of systematic structural modifications on their biological activity.

Gemifloxacin mesylate (GMF), (R,S)-7[(4Z)-3-(aminomethyl)-4-(methoxyimino)-1pyrrolidinyl]-1-cyclopropyl-6-fluoro-1,4-dihydro-4-oxo-1, 8-naphthyridine-3-carboxylic acid methanesulfonate, moxifloxacin (MOX), 1-cyclopropyl-7-[(S,S)2,8-diazabicyclo[4.3.0]non-8yl]-6-fluoro-8-methoxy-1,4-dihydro-4-oxo-3 quinoline carboxylic acid and gatifloxacin (GTF); ( \pm )-1-cyclopropyl-6-fluoro-1,4-dihydro-8-methoxy-7-(3-methyl-1-piperazinyl)-4-oxo-3-quinoline carboxylic acid [2]. GMF, MOX and GTF are fourth-generation synthetic broad-spectrum 8-methoxy fluoroquinolone antibacterial drug derivatives. Due to their clinical advantages, GMF, MOX and GTF are receiving a great interest and there was an increase in number of their pharmaceutical dosage forms in the market in recent past. For routine analysis of the studied drugs, a simple, rapid and cost effective analytical method was required. The chemical structures of the studied fluoroquinolones are shown in (Scheme 1).

No official (pharmacopoeia) method has been found for the assay of GMF, MOX and GTF in their pharmaceutical formulations. Several methods have been reported for the determination of fluoroquinolones either in pure forms, in dosage forms, or in biological fluids like

*Corresponding author. E-mail: aymangouda77@gmail.com 
chromatography [3-9], capillary zone electrophoresis [10, 11], electrochemistry [12-15], atomic absorption spectrometry [16, 17], spectrofluorimetry [18-21] and spectrophotometric methods for GMF [22-28], MOX [16, 29-33] and GTF [16, 34-44]. These methods are associated with some major drawbacks such as decreased selectivity due to measurement in ultraviolet region $[22,23,29,30]$ and/or decreased simplicity of the assay procedure (e.g. tedious precipitation [12] or liquid-liquid extraction [32, 38] steps in the ion-pair formation-based methods). For these reasons, it was worthwhile to develop a new simple and selective spectrophotometric method for the determination of the studied drugs in their pharmaceutical dosage forms.

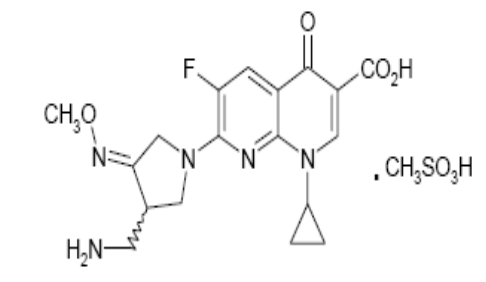

Gemifloxacin mesylate (GMF)

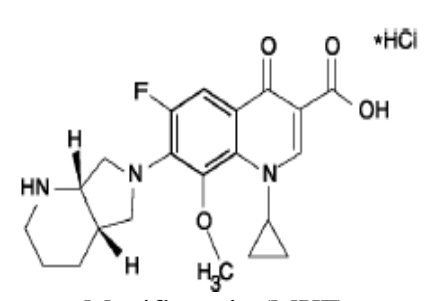

Moxifloxacin (MXF)<smiles>COc1c(N2CCNC(C)C2)c(F)cc2c(=O)c(C(=O)O)cn(C3CC3)c12</smiles>

Gatifloxacin (GTF)

Scheme 1. The chemical structure of the studied drugs.

The kinetic spectrophotometric methods are becoming of a great interest in the pharmaceutical analysis [43, 45]. The application of these methods offered some specific advantages [46] such as (1) simplicity owing to elimination of some experimental steps such as filtration and extraction prior to absorbance measurements; (2) high selectivity due to the measurement of the increase or decrease of the absorbance as a function of reaction time instead of measuring the concrete absorbance value; and (3) absence of interference from the background sample color and/or turbidity and possibility of avoidance of interference from other active compounds present in the commercial product that may be resisting the established reaction conditions.

The literatures are still lacking analytical procedures based on kinetics for determination of the investigated drugs (GMF, MOX and GTF) in commercial dosage forms. No attempts have been made yet to determine the studied drugs by any kinetic spectrophotometric method. The present study describes the development and validation of a selective and simple kinetic spectrophotometric method for the determination of GMF, MOX and GTF by measuring the absorbance at $610 \mathrm{~nm}$ after oxidation reaction with alkaline $\mathrm{KMnO}_{4}$ in an attempt to evaluate the studied drugs in pure forms as well as in dosage forms. 
Apparatus

\section{EXPERIMENTAL}

All absorption spectra were made using Kontron 930 (UV-Visible) spectrophotometer (Germany) with a scanning speed of $200 \mathrm{~nm} / \mathrm{min}$ and a band width of $2.0 \mathrm{~nm}$, equipped with 10 mm matched quartz cells.

\section{Materials and reagents}

All the chemicals were of analytical reagent grade and the solvents were of spectroscopic grade. Pharmaceutical grade gemifloxacin mesylate (GMF) was supplied by El-Obour Modern Pharmaceutical Industries Co., El-obour city, Kaliobeya, Egypt, its potency was $99.99 \pm 0.39 \%$. Moxifloxacin hydrochloride (MOX) reference standard was provided by Sabaa, Kahira Company, Cairo, Egypt, its purity was $100.01 \pm 0.71 \%$. Gatifloxacin sesquihydrate (GTF) reference standard was provided by EPCI, Egyptian Company for Pharmaceutical and Chemical Industries, S.A.E., Beni Suef, Egypt, its potency was $99.65 \pm 0.74 \%$.

\section{Pharmaceutical preparations}

The different pharmaceutical preparations were purchased from the commercial source in the local market. Factive tablets were obtained from Oscient Pharmaceuticals Corporation, USA; Flobiotic tablets were obtained from Hikma Pharmaceuticala PLC, Cairo, Egypt. GemiQue tablets were obtained from El-Obour Modern Pharmaceutical Industries Co., El-obour city, Kaliobeya, Egypt, labelled to contain (320 mg GMF per tablet). Avelox® tablets were obtained from Bayer, Germany, Moxiflox tablets were obtained from EVA Pharm, Cairo, Egypt. Moxifloxacin tablets were obtained from Sabaa International Company for pharmaceuticals and chemical industries, S.A.E. labelled to contain ( $400 \mathrm{mg}$ MOX per tablet). Tequinß tablets were obtained from Bristol Myers Squibb Company, Egypt, Floxin tablets were obtained from Global Napi Co, Egypt. Gatiflox tablets were obtained from (EPCI, Egyptian Company for Pharmaceutical and Chemical Industries, S.A.E., Beni Suef, Egypt), labelled to contain (400 mg GTF per tablet).

\section{Stock solutions}

Stock standard solutions of GMF, MOX and GTF $\left(100 \mu \mathrm{g} \mathrm{mL}^{-1}\right)$ were prepared by dissolving an exact weight $(10 \mathrm{mg})$ of the studied drugs in $2.0 \mathrm{~mL}$ of $0.05 \mathrm{M} \mathrm{NaOH}$, and further diluted to $100 \mathrm{~mL}$ with double distilled water in a $100 \mathrm{~mL}$ measuring flask. These solutions were found to be stable for at least one week without alteration when kept in the refrigerator.

\section{Reagents}

Potassium permanganate (Merck, Germany): $5.0 \times 10^{-3} \mathrm{M}$ aqueous solutions were freshly prepared by dissolving $83.3 \mathrm{mg}$ of pure $\mathrm{KMnO}_{4}$ in $100 \mathrm{~mL}$ of hot double distilled water followed by filtration through sintered glass. Potassium permanganate solutions were freshly prepared and its molarity checked titrimetrically. Sodium hydroxide (El-Nasr Chemical Co., Cairo, Egypt): $0.5 \mathrm{M}$ aqueous solution was prepared by dissolving $2.0 \mathrm{~g} \mathrm{NaOH}$ in $100 \mathrm{~mL}$ of double distilled water.

\section{Recommended general procedures}

Initial rate method. Aliquots of standard GMF, MOX or GTF $\left(100 \mu \mathrm{g} \mathrm{mL}^{-1}\right)$ solutions (0.1-1.6 $\mathrm{mL}$ ) were transferred into a series of $10 \mathrm{~mL}$ calibrated volumetric flasks. To each flask was 
added 1.0 and $1.5 \mathrm{~mL}$ of $0.5 \mathrm{M} \mathrm{NaOH}$ for (GMF or GTF) and MOX, respectively, followed by 1.0 and $1.5 \mathrm{~mL}$ of $5.0 \times 10^{-3} \mathrm{M} \mathrm{KMnO}_{4}$ for (GMF or GTF) and MOX, respectively and the volume was made up to the mark with double distilled water at ambient temperature $\left(25 \pm 2{ }^{\circ} \mathrm{C}\right)$. After mixing, the contents of each flask were immediately transferred to the spectrophotometric cell and the increase in absorbance of the colored manganate ion as a function of time was measured at $610 \mathrm{~nm}$. The initial rate of the reaction $(v)$ at different concentrations was evaluated by measuring the slope of the tangent to the absorbance-time curve. The calibration graphs were constructed by plotting the logarithm the initial rate of reaction $(\log v)$ versus the logarithm of the molar concentration of the drug $(\log C)$. The amount of the drug was calculated either from the calibration graph or the regression equation.

Fixed time method. A fixed times of 9.0, 12 and 15 min for GMF, MOX and GTF, respectively, were selected for the fixed time method. At this preselected fixed time, the absorbance of each sample of drug solution was measured at $610 \mathrm{~nm}$ against a reagent blank prepared similarly except without the drug. The calibration curve was obtained by plotting the absorbance against the initial concentration of drug. The amount of the drug was computed either from a calibration curve or regression equation.

Procedure for the determination of the studied drugs in pharmaceutical formulations

A total of 20 tablets of each drug were mashed and finely powdered. An accurately weighed quantity of the mixed contents of the tablets, equivalent to $100 \mathrm{mg}$ of the drug was extracted into $50 \mathrm{~mL}$ of $0.005 \mathrm{M}$ hydrochloric acid solution, stirred for $15 \mathrm{~min}$ then filtered using Whatmann No. 42 filter paper into a 100-mL volumetric flask to isolate the insoluble excipients. The residue was washed with two $10 \mathrm{~mL}$ portions of $0.005 \mathrm{M}$ hydrochloric acid solution and the washings added to the filtrate and diluted to volume with the same solvent. Aliquots of the tablet solutions were treated as under the above recommended procedures. The nominal content of the tablets was determined either from a previously plotted calibration graph or using the corresponding regression equation.

\section{Determination of the molar ratio}

The Job's method of continuous variation [47] was employed. Stock equimolar solutions $(5.0 \mathrm{x}$ $10^{-4} \mathrm{M}$ ) of drugs and reagent were prepared. Series of $10 \mathrm{~mL}$ portions of the stock solutions of the drugs and the analytical reagent were made up comprising different complementary ratios $[0: 10,1: 9,9: 1,10: 0$, inclusive $]$ in 10-mL calibrated flasks. The solutions were further manipulated as described under the general recommended procedures for each reagent and data treatment.

\section{RESULTS AND DISCUSSION}

\section{Absorption spectra}

The absorption spectrum of aqueous potassium permanganate solution in the alkaline medium exhibited an absorption band at $525 \mathrm{~nm}$. The addition of GMF, MOX or GTF to this solution produced a new characteristic band at $610 \mathrm{~nm}$ (Figure 1) due to the formation of green color manganate ion, which resulted in the oxidation of the studied drugs by potassium permanganate $\left(\mathrm{KMnO}_{4}\right)$ in alkaline medium $(\mathrm{NaOH})$. The intensity of the color was increased with time and therefore, a kinetically based method was developed for the spectrophotometric determination of these drugs in pharmaceutical formulations. The absorbance of the oxidation product remains stable for at least 8.0 hours. 


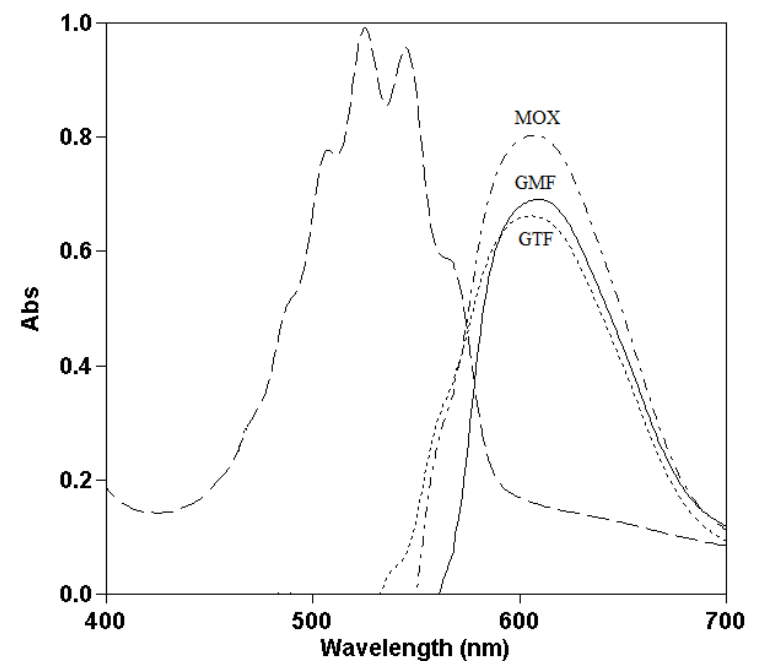

Figure 1. Absorption spectrum of the reaction product of the studied drugs $(20,20$ and $40 \mu \mathrm{g}$ $\mathrm{mL}^{-1}$ ) for GMF, MOX and GTF, respectively, after reaction with $\mathrm{KMnO}_{4}\left(5.0 \times 10^{-3}\right.$ $\mathrm{M})$ in presence of $0.5 \mathrm{M} \mathrm{NaOH}$.

\section{Optimization of the reaction conditions}

The optimum conditions for the proposed method responsible for the formation of green colored manganate ion were studied and maintained throughout the experiment. The spectrophotometric properties of the colored product as well as the different experimental parameters affecting the color development and its stability were carefully studied and optimized. Such factors were changed individually while the others were kept constant. These factors include concentration of the reagents $\left(\mathrm{KMnO}_{4}\right.$ and $\left.\mathrm{NaOH}\right)$, diluting solvents, and temperature.

\section{Effect of $\mathrm{KMnO}_{4}$ concentration}

The effect of the $\mathrm{KMnO}_{4}$ concentration on the initial rate of the reaction (v) was studied using different volumes $(0.25-3.0 \mathrm{~mL})$ of $5.0 \times 10^{-3} \mathrm{M} \mathrm{KMnO}_{4}$ or in the range $1.25 \times 10^{-4}$ to $1.5 \times 10^{-3}$ $\mathrm{M}$. The initial rate of reaction and hence maximum absorbance increased with increasing the concentration of $\mathrm{KMnO}_{4}$ and became constant at $1.0 \mathrm{~mL}$ of $5.0 \times 10^{-3} \mathrm{M} \mathrm{KMnO}_{4}\left(5.0 \times 10^{-4} \mathrm{M}\right)$ for (GMF or GTF) and $1.5 \mathrm{~mL}$ of $7.5 \times 10^{-4} \mathrm{M} \mathrm{KMnO}_{4}\left(5.0 \times 10^{-3} \mathrm{M}\right)$ for MOX. Thus, the adoption of $5.0 \times 10^{-3} \mathrm{M} \mathrm{KMnO}_{4}$ in the final solution proved to be adequate for the maximum concentration of GMF, MOX or GTF used in the determination process (Figure 2).

\section{Effect of sodium hydroxide concentration}

The influence of the concentration of $\mathrm{NaOH}$ on the absorbance of the reaction product $\left(\mathrm{MnO}_{4}{ }^{-2}\right)$ and the reaction rate was also examined by taking 20,24 and $40 \mu \mathrm{g} \mathrm{mL}^{-1}$ of GMF, MOX and GTF, respectively, $1.5 \mathrm{~mL}$ of $5.0 \times 10^{-3} \mathrm{M} \mathrm{KMnO}_{4}$ solution and varying volume $(0.25-3.0 \mathrm{~mL})$ of $0.5 \mathrm{M} \mathrm{NaOH}$. The maximum absorbance was obtained with 1.0 and $1.5 \mathrm{~mL}$ of $0.5 \mathrm{M} \mathrm{NaOH}$ for (GMF or GTF) and MOX, respectively, after which further increase in volume of $\mathrm{NaOH}$ caused no change in absorbance. Hence, $1.5 \mathrm{~mL}$ of $0.5 \mathrm{M} \mathrm{NaOH}$ was found to be the most suitable concentration for maximum absorbance (Figure 3 ). 


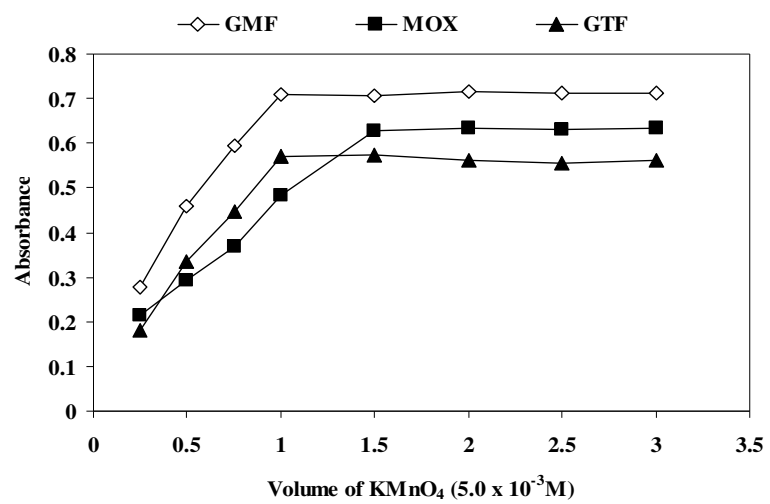

Figure 2. Effect of volume $(\mathrm{mL})$ of $\mathrm{KMnO}_{4}\left(5.0 \times 10^{-3} \mathrm{M}\right)$ on the absorbance of the reaction products at the optimum wavelengths.

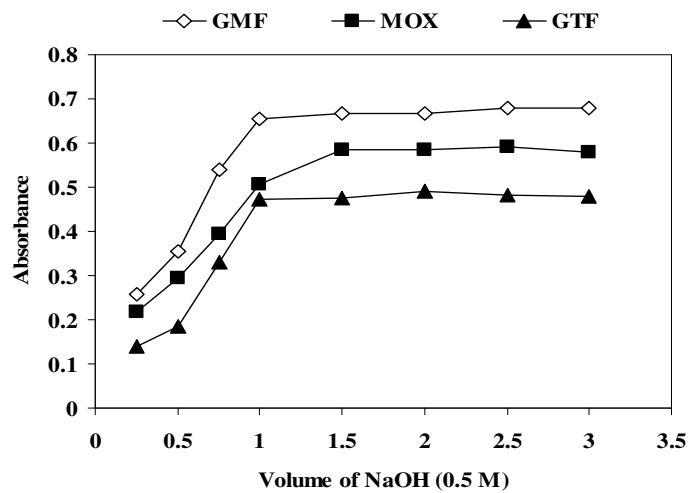

Figure 3. Effect of volume $(\mathrm{mL})$ of $\mathrm{NaOH}(0.5 \mathrm{M})$ on the absorbance of the reaction products at the optimum wavelengths.

Effect of temperature

The effect of temperature on the initial rate of reaction was studied. The reaction was carried out at room temperature $\left(25^{\circ} \mathrm{C}\right)(298 \mathrm{~K})$ and at elevated temperatures $\left(40-100{ }^{\circ} \mathrm{C}\right)$ using a thermostatically controlled water bath. It was observed that the studied drugs react faster with potassium permanganate and the color intensity slightly increased with temperature. At higher temperatures the reaction product decomposed and manganese dioxide $\left(\mathrm{MnO}_{2}\right)$ produced resulting in poor reproducibility. Nevertheless, the subsequent experiments were carried out at room temperature to simplify the analytical procedure (i.e. avoid using extra equipment; water bath) on the expense of lower limit of detection.

Effect of diluting solvent

The effect of diluting solvent was also studied. Different solvents such as double distilled water, ethanol, acetonitrile and dimethyl sulfoxide were used. It was found that double distilled water was the best solvent as it gave the highest absorbance reading, which offered distinct advantage over other methods. 


\section{Stoichiometry and reaction mechanism}

The stoichiometry of the reaction of $\mathrm{KMnO}_{4}$ with each of the studied drugs was investigated by Job's method [47]. The results indicated that the ratio of drug to $\mathrm{KMnO}_{4}$ was $1: 1$. Based on this ratio, the reaction path-way was postulated to proceed as shown in Scheme 2. The reaction was first order with respect to the drug concentration.

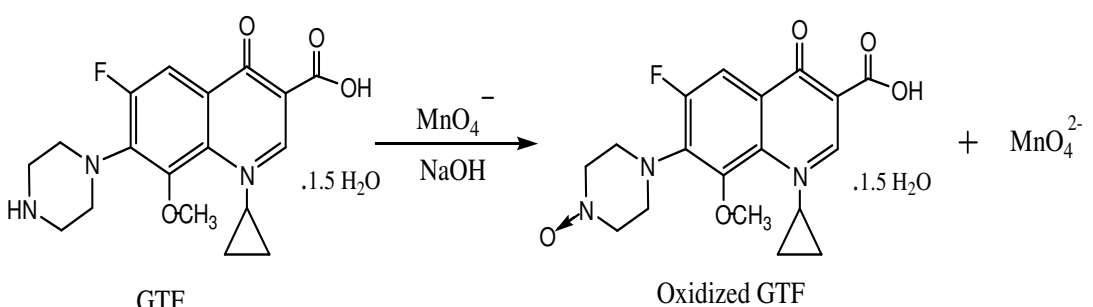

Scheme 2. The reaction pathway of GTF with $\mathrm{KMnO}_{4}$ in presence of $\mathrm{NaOH}$.

\section{Kinetics study of the reactions}

The stoichiometry of the reaction was studied by the limiting logarithmic method [48]. This was established by performing two sets of experiments. In the first set, $\mathrm{KMnO}_{4}$ concentration was varied while keeping a constant concentration of drug. In the second set, the $\mathrm{KMnO}_{4}$ concentration was kept constant while varying the concentration of drug. The logarithms of the absorbance were plotted against the logarithm of [drug] or $\left[\mathrm{KMnO}_{4}\right]$ concentration (Figure $4 \mathrm{~A}$ and B) to evaluate the slope of the respective line to determine the order of reaction of the drug with respect to $\mathrm{KMnO}_{4}$ or vice versa. The slopes of the two straight lines were calculated and found to be unity in each case.

A plot of $\log$ absorbance versus $\log \left[\mathrm{KMnO}_{4}\right]$ gave slope values of $0.9125,1.0063$ and 0.8609 for GMF, MOX and GTF, respectively. Also plot of log absorbance versus log [Drug] gave straight lines with slopes of $0.9498,0.8566$ and 0.9776 for GMF, MOX and GTF, respectively. Thus, it was concluded that the combining molar ratio between drug and $\mathrm{KMnO}_{4}$ is $1: 1$. Hence the results indicated that a mole of potassium permanganate is consumed by a mole of the drug.

\section{Evaluation of the kinetic parameters}

Under the optimized experimental conditions, the concentration of each drug was determined using an excess of $\mathrm{KMnO}_{4}$ and $\mathrm{NaOH}$ solution with respect to the initial concentration of drug. As a result, a pseudo first order condition was obtained with respect to their concentrations. However, the initial rate of the reaction revealed to follow a pseudo first order and was found to obey the following equation:

Rate of the reaction $(v)=d x / d t=K^{1} C^{n}{ }_{\text {drug }} C^{m}{ }_{\mathrm{KMnO} 4} C^{1}{ }_{\mathrm{NaOH}}$

For $\mathrm{C} \mathrm{KMnO}_{4} \geq 1.0 \times 10^{-3} \mathrm{M}$ and $\mathrm{C} \mathrm{NaOH} \geq 1.0 \times 10^{-1} \mathrm{M}$. Equation 1 could be reduced to equation 2.

Rate of the reaction $=\Delta \mathrm{A} / \Delta \mathrm{t}=K^{\prime} \mathrm{C}^{n}$

where $\mathrm{K}^{\prime}$ is the pseudo first order rate constant, $\mathrm{C}$ is the concentration of drug, $\mathrm{n}$ is the order of the reaction. 


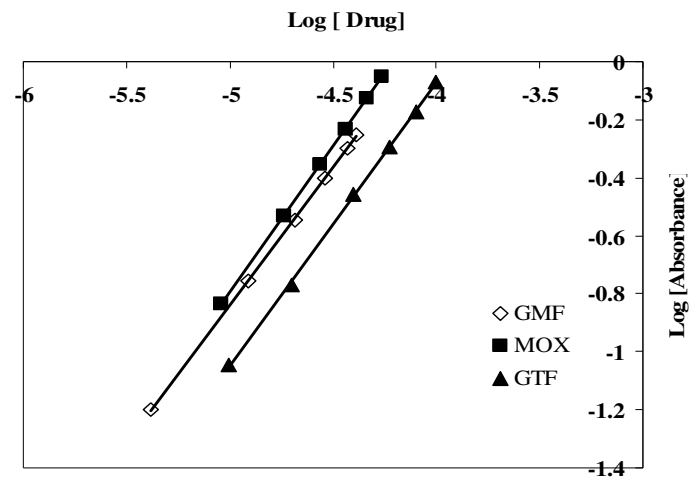

(A)

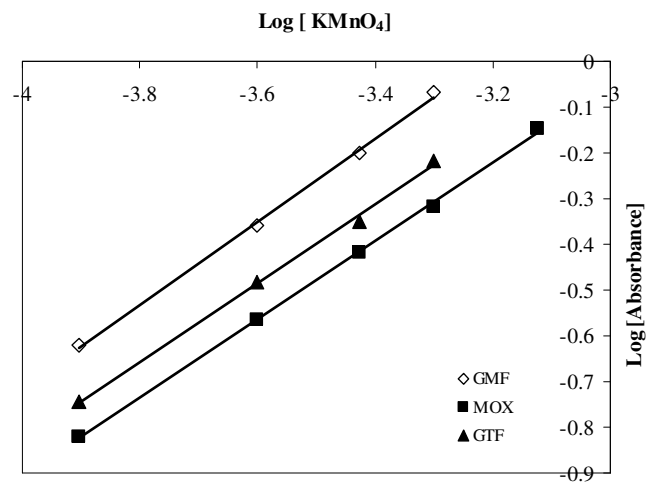

(B)

Figure 4. Limiting logarithmic plots for the molar ratio: (A) log A vs. $\log$ [Drug] (B) $\log$ A vs. $\log \left[\mathrm{KMnO}_{4}\right]$.

Table 1. Lograthims of rates for different concentrations of GMF, MOX and GTF at room temperatures and $610 \mathrm{~nm}$.

\begin{tabular}{|c|c|c|c|c|c|}
\hline $\log \Delta \mathrm{A} / \Delta \mathrm{t}$ & $\log [\mathrm{GMF}](\mathrm{M})$ & $\log \Delta \mathrm{A} / \Delta \mathrm{t}$ & $\log [\mathrm{MOX}](\mathrm{M})$ & $\log \Delta \mathrm{A} / \Delta \mathrm{t}$ & $\log [\mathrm{GTF}](\mathrm{M})$ \\
\hline-4.531 & -5.385 & -4.0 & -5.0393 & -4.155 & -5.003 \\
\hline-4.111 & -4.908 & -3.699 & -4.7383 & -3.846 & -4.695 \\
\hline-3.928 & -4.6862 & -3.523 & -4.56225 & -3.583 & -4.4006 \\
\hline-3.796 & -4.54 & -3.398 & -4.437 & -3.408 & -4.2245 \\
\hline-3.7213 & -4.431 & -3.301 & -4.34 & -3.275 & -4.0995 \\
\hline-3.68 & -4.385 & -3.231 & -4.261 & -3.195 & -4.0026 \\
\hline
\end{tabular}

The rate of the reaction may be estimated by the variable-time method measurement as $\Delta \mathrm{A} / \Delta \mathrm{t}$, where $A$ is the absorbance and $t$ is the time in seconds. Taking logarithms of rates and drug concentrations (Table 1), Eq. 2 is transformed to:

$\log ($ rate $)=\log \Delta A / \Delta t=\log k^{\prime}+n \log [\mathrm{C}]$ 
The linear regression analysis using the method of least square was made to evaluate slope, intercept and correlation coefficient, pseudo-order rate constant and order of the reaction which are indicated in Table 1.

Under the optimized experimental conditions a calibration curve was constructed by plotting $\log$ initial rate $(\log v)$ versus $\log$ molar concentration of drug $(\log C)$ at $610 \mathrm{~nm}$ for GMF, MOX and GTF, respectively, which showed a linear relationship over drug concentration range of 2.0-20, 4.0-24 and 4.0-40 $\mu \mathrm{g} \mathrm{mL}^{-1}$ for GMF, MOX and GTF, respectively (Figures 5, 6 and 7). These results indicate that the reaction is pseudo first order reaction in the drug concentration. The regression of $\log$ rate versus $\log \mathrm{C}$ gave a linear regression equation:

$$
\begin{array}{ll}
\log (\text { rate })=\log \Delta A / \Delta t=0.0574-0.851 \log [\mathrm{GMF}], & \mathrm{r}=0.9994 \\
\log (\text { rate })=\log \Delta A / \Delta t=1.0056+0.993 \log [\mathrm{MOX}], & \mathrm{r}=0.9999 \\
\log (\text { rate })=\log \Delta A / \Delta t=0.6494+0.9596 \log [\mathrm{GTF}], & \mathrm{r}=0.9995
\end{array}
$$

Hence $\mathrm{K}^{\prime}=1.14,10.13$ and $4.46 \mathrm{~s}^{-1}$ for GMF, MOX and GTF, respectively, the reaction is pseudo-first-order $(\mathrm{n} \approx 1)$ with respect to either of the three drugs.

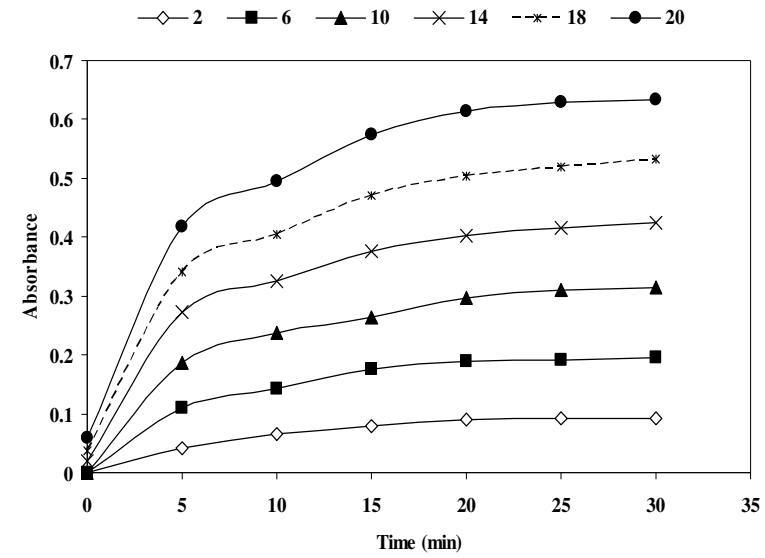

Figure 5. Absorption versus time graphs for the reaction between GMF and $\mathrm{KMnO}_{4}$ at $610 \mathrm{~nm}$ 1) $2.0 \mu \mathrm{g} \mathrm{mL}^{-1}$ 2) $6.0 \mu \mathrm{g} \mathrm{mL}^{-1}$ 3) $10 \mu \mathrm{g} \mathrm{mL}^{-1}$ 4) $14 \mu \mathrm{gL}^{-1}$ 5) $18 \mu \mathrm{g} \mathrm{mL}^{-1}$ 6) $20 \mu \mathrm{g} \mathrm{mL}^{-1}$.

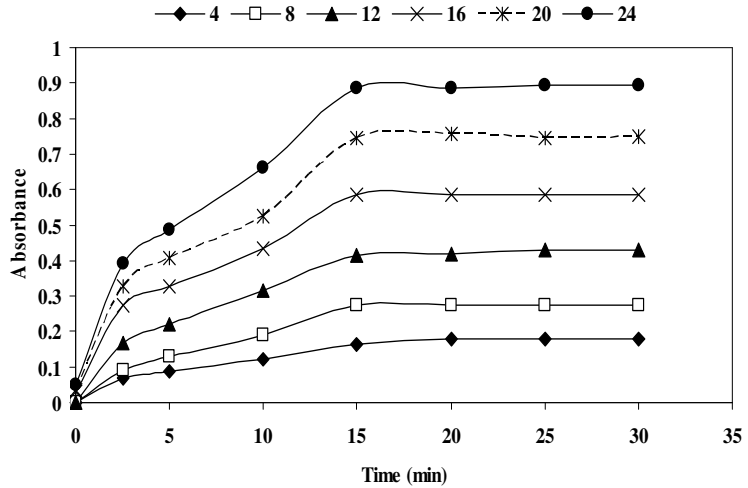

Figure 6. Absorption vs time graphs for the reaction between $\mathrm{MOX}$ and $\mathrm{KMnO}_{4}$ at $610 \mathrm{~nm} \mathrm{1}$ ) $4.0 \mu \mathrm{g} \mathrm{mL}^{-1}$ 2) $8.0 \mu \mathrm{g} \mathrm{mL}^{-1}$ 3) $12 \mu \mathrm{g} \mathrm{mL}^{-1}$ 4) $16 \mu \mathrm{g} \mathrm{mL}^{-1}$ 5) $20 \mu \mathrm{g} \mathrm{mL}^{-1}$ 6) $24 \mu \mathrm{g} \mathrm{mL}^{-1}$.

Bull. Chem. Soc. Ethiop. 2013, 27(3) 


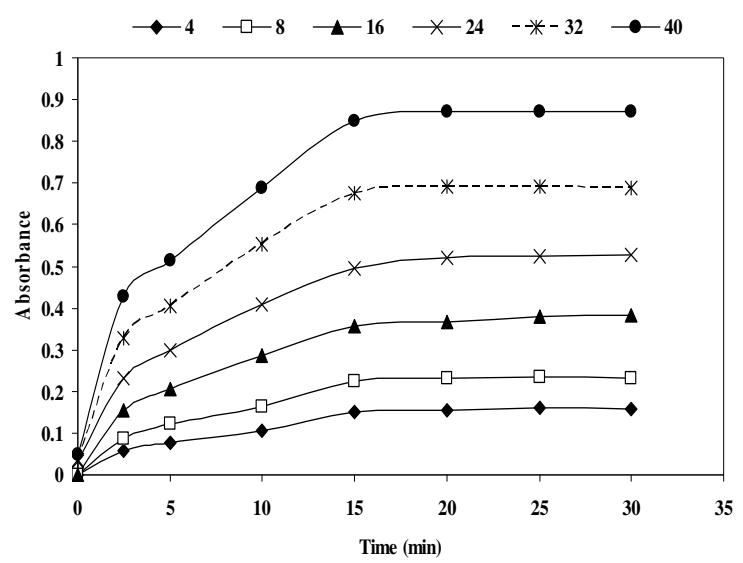

Figure 7. Absorption versus time graphs for the reaction between $\mathrm{GTF}$ and $\mathrm{KMnO}_{4}$ at $610 \mathrm{~nm}$ 1) $4.0 \mu \mathrm{g} \mathrm{mL}^{-1}$ 2) $8.0 \mu \mathrm{g} \mathrm{mL}^{-1}$ 3) $16 \mu \mathrm{g} \mathrm{mL}^{-1}$ 4) $24 \mu \mathrm{g} \mathrm{mL}^{-1}$ 5) $32 \mu \mathrm{g} \mathrm{mL}^{-1}$ 6) $40 \mu \mathrm{g} \mathrm{mL}^{-1}$.

The apparent rate constant and activation energy

The absorbance-time curves at different temperatures $\left(25-100{ }^{\circ} \mathrm{C}\right)$ were generated using fixed concentration of each drug and $\mathrm{KMnO}_{4}\left(5.0 \times 10^{-3} \mathrm{M}\right)$. From these curves the apparent rate constants were calculated. The activation energy, defined as the minimum kinetic energy that a molecule possesses in order to undergo a reaction was determined using Arrhenius equation [49].

$\log \mathrm{k}=\log A-\mathrm{E}_{\mathrm{a}} / 2.303 \mathrm{RT}$

where $\mathrm{k}$ is the apparent rate constant, $A$ is the frequency factor, $\mathrm{E}_{\mathrm{a}}$ is the activation energy, $\mathrm{T}$ is the absolute temperature $\left({ }^{\circ} \mathrm{C}+273\right)$, and $\mathrm{R}$ is the gas constant $\left(1.987\right.$ calories degree $\left.\mathrm{mol}^{-1}\right)$. The values of $\log \mathrm{k}$ were plotted as a function of $1 / \mathrm{T}$. Straight lines with slope $\left(=-\mathrm{E}_{\mathrm{a}} / 2.303 \mathrm{R}\right)$ values of $-258,-231$ and -251 for GMF, MOX and GTF, respectively, were obtained (Figure 8). From these data, the activation energy was calculated and found to be $4.93,4.43$ and $4.81 \mathrm{~kJ}$ $\mathrm{mol}^{-1}$ for GMF, MOX and GTF, respectively. These low activation energies explained that $\mathrm{KMnO}_{4}$ could be used as a useful reagent in the development of a sensitive spectrophotometric method for the determination of GMF, MOX and GTF.

\section{Appraisal of kinetic methods}

The quantitation of the studied drugs GMF, MOX and GTF under the optimized experimental conditions mentioned above would result in pseudo-first-order with respect to their concentrations where $\mathrm{KMnO}_{4}$ concentration was at least 121 times of the initial concentration of GMF, at least 50 times of the initial concentration of GTF, or at least 164 times the initial concentration of MOX. However, the rate of reaction will be directly proportional to the drug concentration in a pseudo-first-order rate equation as follows:

Rate $=\mathrm{K}^{\prime}[\mathrm{drug}]$

where $\mathrm{K}^{\prime}$ is the pseudo-first-order rate constant. Equation 5 was the basis for several experiments, which were performed to obtain the drug concentration using the rate data. Initial rate, rate constant, fixed-concentration and fixed-time methods [50] were tested and the most 
suitable analytical method was selected taking into account the applicability, the sensitivity (i.e. the slope of the calibration graph), correlation coefficient (r) and intercept (a).

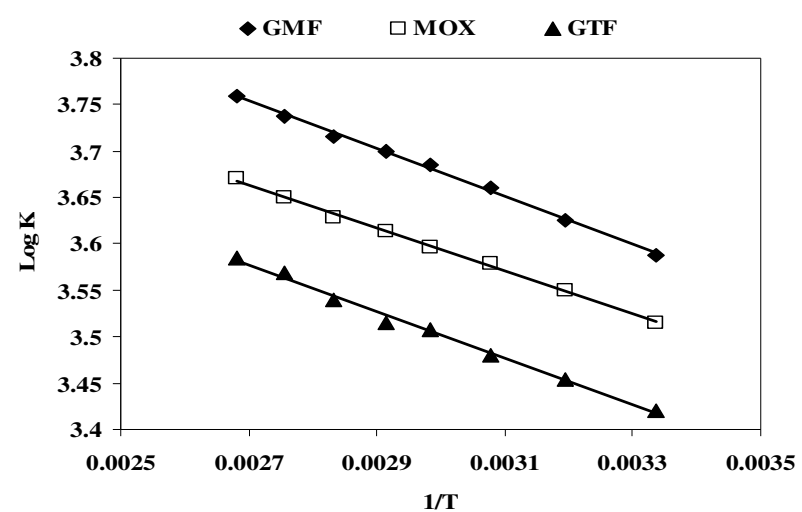

Figure 8. Arrhenius plot for the reaction of $\mathrm{KMnO}_{4}\left(5.0 \times 10^{-3} \mathrm{M}\right)$ with the studied drugs in presence of $\mathrm{NaOH}(0.5 \mathrm{M})$. $\mathrm{T}$ and $\mathrm{K}$ are the absolute temperature and the apparent rate constant, respectively.

Initial-rate method

In this method, graphs of the rate (at the beginning of the reaction) versus drug concentration were not easy to obtain, because the first step of the reaction was too fast to follow, so tangents of the curve at zero-time were not easy to draw. Therefore, this method could not be applied.

\section{Rate-constant method}

The best way to obtain an average $\mathrm{K}$ value for the reaction is to plot the logarithm of the concentration or the logarithm of any related property versus time. The slope of the line is $-K^{\prime} / 2.303$, from which the rate constant is obtained. If a straight line is obtained, it indicates that the reaction is first order.

Graphs of $\log$ (absorbance) versus time over the concentration ranges $4.12 \times 10^{-6}-4.12 \times$ $10^{-5} \mathrm{M}\left(2.0-20 \mu \mathrm{g} \mathrm{mL}^{-1}\right)$ for GMF, $9.13 \times 10^{-6}-5.48 \times 10^{-5} \mathrm{M}\left(4.0-24 \mu \mathrm{g} \mathrm{mL}^{-1}\right)$ for MOX and $9.94 \times 10^{-6}-9.94 \times 10^{-5} \mathrm{M}\left(4.0-40 \mu \mathrm{g} \mathrm{mL}^{-1}\right)$ for GTF were plotted and all appeared to be rectilinear. Pseudo-first-order rate constants $\left(\mathrm{K}^{\prime}\right)$ corresponding to different concentrations of the investigated drugs $[\mathrm{C}]$ were calculated from the slopes multiplied by -2.303 (Table 2 ). Regression of $\mathrm{K}^{\prime}$ versus [C] gave the equations:

$$
\begin{array}{lr}
\mathrm{K}^{\prime}=-9.0 \times 10^{-4}+16.305[\mathrm{GMF}], & (\mathrm{r}=0.9974) \\
\mathrm{K}^{\prime}=-1.4 \times 10^{-3}+16.346[\mathrm{MOX}], & (\mathrm{r}=0.9909) \\
\mathrm{K}^{\prime}=-1.2 \times 10^{-3}+9.1646[\mathrm{GTF}], & (\mathrm{r}=0.9991)
\end{array}
$$

The r-values indicate relatively poor linearity which is probably due to inconsistency of $\mathrm{K}^{\prime}$ as a result of the inevitable slight changes in temperature of the reaction. 
Table 2. Values of rate constant $\mathrm{K}^{\prime}$ calculated from slopes Log A $v s$ time graphs at $610 \mathrm{~nm}$.

\begin{tabular}{|c|c|c|c|c|c|}
\hline$[\mathrm{GMF}](\mathrm{M})$ & $\mathrm{K}^{\prime}\left(\mathrm{s}^{-1}\right)$ & {$[\mathrm{MOX}](\mathrm{M})$} & $\mathrm{K}^{\prime}\left(\mathrm{s}^{-1}\right)$ & {$[\mathrm{GTF}](\mathrm{M})$} & $\mathrm{K}^{\prime}\left(\mathrm{s}^{-1}\right)$ \\
\hline $4.12 \times 10^{-6}$ & $-8.71 \times 10^{-4}$ & $9.135 \times 10^{-6}$ & $-1.3127 \times 10^{-3}$ & $9.94 \times 10^{-6}$ & $-1.082 \times 10^{-3}$ \\
\hline $1.234 \times 10^{-5}$ & $-7.31 \times 10^{-4}$ & $1.823 \times 10^{-5}$ & $-1.1515 \times 10^{-3}$ & $1.988 \times 10^{-5}$ & $-9.80 \times 10^{-4}$ \\
\hline $2.06 \times 10^{-5}$ & $-5.8 \times 10^{-4}$ & $2.74 \times 10^{-5}$ & $-9.673 \times 10^{-4}$ & $3.976 \times 10^{-5}$ & $-7.85 \times 10^{-4}$ \\
\hline $2.88 \times 10^{-5}$ & $-4.61 \times 10^{-4}$ & $3.654 \times 10^{-5}$ & $-8.061 \times 10^{-4}$ & $5.964 \times 10^{-5}$ & $-6.22 \times 10^{-4}$ \\
\hline $3.71 \times 10^{-5}$ & $-3.45 \times 10^{-4}$ & $4.567 \times 10^{-5}$ & $-6.91 \times 10^{-4}$ & $7.952 \times 10^{-5}$ & $-4.45 \times 10^{-4}$ \\
\hline $4.12 \times 10^{-5}$ & $-2.51 \times 10^{-4}$ & $5.481 \times 10^{-5}$ & $-5.76 \times 10^{-4}$ & $9.94 \times 10^{-5}$ & $-2.50 \times 10^{-4}$ \\
\hline
\end{tabular}

\section{Fixed-concentration method}

Reaction rates were determined for different concentrations of the investigated drugs. A preselected absorbance value was fixed ( 0.3 for both MOX and GMF) for different concentrations of the two drugs, in the range $2.06 \times 10^{-5}-4.12 \times 10^{-5} \mathrm{M}\left(10-20 \mu \mathrm{g} \mathrm{mL}^{-1}\right)$ for GMF, $2.74 \times 10^{-5}$ $-5.481 \times 10^{-5} \mathrm{M}\left(12-24 \mu \mathrm{g} \mathrm{mL}{ }^{-1}\right)$ for MOX and $3.976 \times 10^{-5}-9.94 \times 10^{-5} \mathrm{M}\left(16-40 \mu \mathrm{g} \mathrm{mL}^{-1}\right)$ for GTF. The time required for each concentration to reach the pre-selected absorbance value was measured in seconds. The reciprocal of time $(1 / \mathrm{t})$ was plotted versus the initial concentrations of the drug (Table 3) and the following equations were obtained by linear regression:

$$
\begin{array}{ll}
1 / \mathrm{t}=-3.3 \times 10^{-3}+196.86[\mathrm{GMF}], & \mathrm{r}=0.9994 \\
1 / \mathrm{t}=-6.2 \times 10^{-3}+291.7[\mathrm{MOX}], & \mathrm{r}=0.9997 \\
1 / \mathrm{t}=-6.7 \times 10^{-3}+185.01[\mathrm{GTF}], & \mathrm{r}=0.9992
\end{array}
$$

Although the correlation coefficient values are acceptable ( $>0.999)$ the method still suffers from the narrow linearity ranges.

Table 3. Values of reciprocal time taken at fixed absorbance for the different rates of variable concentration of drugs at constant concentrations of $\mathrm{KMnO}_{4}$.

\begin{tabular}{|c|c|c|c|c|c|}
\hline$[\mathrm{GMF}](\mathrm{M})$ & $1 / \mathrm{t}\left(\mathrm{s}^{-1}\right)$ & {$[\mathrm{MOX}](\mathrm{M})$} & $1 / \mathrm{t}\left(\mathrm{s}^{-1}\right)$ & {$[\mathrm{GTF}](\mathrm{M})$} & $1 / \mathrm{t}\left(\mathrm{s}^{-1}\right)$ \\
\hline $2.06 \times 10^{-5}$ & $7.94 \times 10^{-4}$ & $2.74 \times 10^{-5}$ & $1.85 \times 10^{-3}$ & $3.976 \times 10^{-5}$ & $8.0 \times 10^{-4}$ \\
\hline $2.88 \times 10^{-5}$ & $2.38 \times 10^{-3}$ & $3.654 \times 10^{-5}$ & $4.40 \times 10^{-3}$ & $5.964 \times 10^{-5}$ & $4.22 \times 10^{-3}$ \\
\hline $3.71 \times 10^{-5}$ & $3.97 \times 10^{-3}$ & $4.567 \times 10^{-5}$ & $7.20 \times 10^{-3}$ & $7.952 \times 10^{-5}$ & $7.94 \times 10^{-3}$ \\
\hline $4.12 \times 10^{-5}$ & $4.88 \times 10^{-3}$ & $5.481 \times 10^{-5}$ & $9.80 \times 10^{-3}$ & $9.94 \times 10^{-5}$ & $1.18 \times 10^{-2}$ \\
\hline
\end{tabular}

\section{Fixed-time method}

Reaction rates were determined for different concentrations of the studied drugs. At a preselected fixed time, which was accurately determined, the reaction was quenched by cooling and absorbance was measured. Calibration graphs of the absorbance (A) versus initial concentration [C] were established at different fixed-time intervals of 5.0-30 min. At each fixed-time, regression equation parameters were calculated and it was found that the slopes increase with time and the most acceptable values for the intercept and the correlation coefficient ( $r$ ) were obtained at a fixed time of $20 \mathrm{~min}$ for GMF and $15 \mathrm{~min}$ for MOX and GTF, which were therefore chosen as the most suitable time intervals for measurements. Calibration graphs were linear over the concentration ranges mentioned in Table 4. 
Table 4. Regression equations for the studied drugs at fixed time.

\begin{tabular}{|c|c|c|c|c|c|c|}
\hline $\begin{array}{c}\text { Time } \\
(\mathrm{min})\end{array}$ & \multicolumn{2}{|c|}{ GMF } & \multicolumn{2}{c|}{ MOX } & \multicolumn{2}{c|}{ GTF } \\
\hline & $\begin{array}{c}\text { Regression } \\
\text { equation }\end{array}$ & $\begin{array}{c}\text { Correlation } \\
\text { coefficient }(\mathrm{r})\end{array}$ & $\begin{array}{c}\text { Regression } \\
\text { equation }\end{array}$ & $\begin{array}{c}\text { Correlation } \\
\text { coefficient }(\mathrm{r})\end{array}$ & $\begin{array}{c}\text { Regression } \\
\text { equation }\end{array}$ & $\begin{array}{c}\text { Correlation } \\
\text { coefficient }(\mathrm{r})\end{array}$ \\
\hline 5 & $\mathrm{~A}=0.0197 \mathrm{C}-$ & 0.9975 & $\mathrm{~A}=0.0201 \mathrm{C}+$ & 0.9986 & $\mathrm{~A}=0.0125 \mathrm{C}+$ & 0.9989 \\
& 0.0026 & & 0.0024 & & 0.0063 & \\
\hline 10 & $\mathrm{~A}=0.0223 \mathrm{C}+$ & 0.9991 & $\mathrm{~A}=0.0262 \mathrm{C}+$ & 0.9991 & $\mathrm{~A}=0.0169 \mathrm{C}+$ & 0.9991 \\
& 0.007 & & 0.0056 & & 0.0116 & \\
\hline 15 & $\mathrm{~A}=0.0258 \mathrm{C}+$ & 0.9991 & $\mathrm{~A}=0.037 \mathrm{C}-$ & 0.9999 & $\mathrm{~A}=0.0211 \mathrm{C}+$ & 0.9998 \\
& 0.0049 & & 0.0017 & & 0.0031 & \\
\hline 20 & $\mathrm{~A}=0.0278 \mathrm{C}+$ & 0.9998 & $\mathrm{~A}=0.0373 \mathrm{C}+$ & 0.9990 & $\mathrm{~A}=0.0214 \mathrm{C}+$ & 0.9991 \\
& 0.0054 & & 0.0039 & & 0.0142 & \\
\hline 25 & $\mathrm{~A}=0.03 \mathrm{C}+$ & 0.9953 & $\mathrm{~A}=0.0373 \mathrm{C}-$ & 0.9982 & $\mathrm{~A}=0.0216 \mathrm{C}+$ & 0.9991 \\
& 0.01 & & 0.0013 & & 0.0075 & \\
\hline 30 & $\mathrm{~A}=0.0299 \mathrm{C}+$ & 0.9955 & $\mathrm{~A}=0.038 \mathrm{C}-$ & 0.9977 & $\mathrm{~A}=0.022 \mathrm{C}+$ & 0.9990 \\
& 0.0144 & & 0.0051 & & 0.014 & \\
\hline
\end{tabular}

Validation of the method

\section{Linearity}

After optimizing the reaction conditions, the fixed time was applied to the determination of the studied drugs in pure form over the concentration ranges of $2.0-20,4.0-24$ and $4.0-40 \mu \mathrm{g} \mathrm{mL}^{-1}$ for GMF, MOX and GTF, respectively. Linear plots $(n=6)$ with good correlation coefficients were obtained. Table 5 present the performance data for the proposed spectrophotometric method, including molar absorptivities, Sandell's sensitivities, linearity ranges and regression equations calculated from calibration graphs. Other statistical parameters such as the intercept (a), the slope (b) and the relative standard deviation, relative error percentages are also given in Table 5. The high values of the correlation coefficients of the regression equations indicate good linearity over the working concentration ranges. The \% recoveries of the three studied drugs compared with that obtained by the reported methods were given in Table 5. Statistical analysis [51] of the results obtained by the proposed and reference methods; GMF [25], MOX [33] and GTF [16] using student's t-test and variance ratio F-value revealed no significant difference between the performance of the two methods regarding the accuracy and precision.

Detection and quantitation limits

In accordance with the recommendations of (ICH, 2005) [52] the limit of detection was evaluated from the relationship, $\mathrm{LOD}=3.3 \sigma / \mathrm{s}$, where $\sigma$ is the standard deviation of replicate determinations of the blank and $\mathrm{s}$ is the slope of the calibration graph. On the other hand, the limit of quantitation, LOQ, is defined as $10 \sigma / \mathrm{s}$. The detection and quantitation limits of the studied fluoroquinolones using the proposed spectrophotometric procedure are presented in Table 5. Obviously, the LOD and LOQ values as well as the concentration ranges are lower due to the higher sensitivity which is offered by this technique.

\section{Precision and Accuracy}

The accuracy and precision of the proposed methods were carried out by six determinations at four different concentrations. Percentage relative standard deviation (RSD\%) as precision and percentage relative error (RE\%) as accuracy of the suggested method were calculated. Table 6 shows the values of relative standard deviations for different concentrations of the drugs determined from the calibration curves. These results of accuracy and precision showed that the 
proposed methods have good repeatability and reproducibility. The proposed methods were found to be selective for the estimation of GMF, MOX and GTF in the presence of various tablet excipients. For this purpose, a powder blend using typical tablet excipients was prepared along with the drug and then analyzed. The recoveries were not affected by the excipients and the excipients blend did not show any absorption in the range of analysis.

Table 5. Experimental and analytical parameters for the kinetic spectrophotometric determination of the studied drugs using $\mathrm{KMnO}_{4}$.

\begin{tabular}{|c|c|c|c|}
\hline Parameter & GMF & MOX & GTF \\
\hline Volume of $\mathrm{NaOH}(\mathrm{mL})$ & 1.0 & 1.5 & 1.0 \\
\hline Volume of $5.0 \times 10^{-3} \mathrm{M} \mathrm{KMnO}_{4}(\mathrm{~mL})$ & 1.0 & 1.5 & 1.0 \\
\hline Reaction time (min.) & 20 & 15 & 15 \\
\hline$\lambda_{\max }(\mathrm{nm})$ & 610 & 610 & 610 \\
\hline Concentration range $[\mathrm{M}]$ & $\begin{array}{l}4.12 \times 10^{-6}- \\
4.12 \times 10^{-5}\end{array}$ & $\begin{array}{l}9.135 \times 10^{-6}- \\
5.481 \times 10^{-5}\end{array}$ & $\begin{array}{l}9.94 \times 10^{-6}- \\
9.94 \times 10^{-5}\end{array}$ \\
\hline Concentration range $\left(\mu \mathrm{g} \mathrm{mL}^{-1}\right)$ & $2.0-20$ & $4.0-24$ & $4.0-40$ \\
\hline Molar absorptivity $(\varepsilon)\left(\mathrm{L} \mathrm{mol}^{-1} \mathrm{~cm}^{-1}\right)$ & $1.067 \times 10^{4}$ & $1.6113 \times 10^{4}$ & 0.8646 \\
\hline Sandell's sensitivity $\left(\mu \mathrm{g} \mathrm{cm}^{-2}\right)$ & 0.04551 & 0.02718 & 0.04654 \\
\hline \multicolumn{4}{|l|}{ Regression equation $^{\mathrm{a}}$} \\
\hline Slope & 0.0278 & 0.037 & 0.0211 \\
\hline Intercept & 0.0054 & -0.0017 & 0.0031 \\
\hline Correlation coefficient $(\mathrm{r})$ & 0.9998 & 0.9999 & 0.9998 \\
\hline $\mathrm{LOD}[\mathrm{M}],\left(\mu \mathrm{g} \mathrm{mL}^{-1}\right)$ & $8.65 \times 10^{-7},(0.42)$ & $1.62 \times 10^{-6},(0.71)$ & $1.566 \times 10^{-6},(0.63)$ \\
\hline LOQ [M], $\left(\mu \mathrm{g} \mathrm{mL}^{-1}\right)$ & $2.88 \times 10^{-6},(1.4)$ & $5.41 \times 10^{-6},(2.37)$ & $5.22 \times 10^{-6},(2.10)$ \\
\hline Recovery $\% \pm$ SD & $100.58 \pm 0.774$ & $100.0 \pm 0.63$ & $99.87 \pm 0.73$ \\
\hline RSD\% & 0.77 & 0.63 & 0.73 \\
\hline RE\% & 0.81 & 0.66 & 0.77 \\
\hline t- value ${ }^{b}$ & $1.02(2.57)$ & $0.65(2.78)$ & $0.15(2.57)$ \\
\hline F- value $^{b}$ & $1.61(5.05)$ & $1.86(5.19)$ & $1.03(5.05)$ \\
\hline
\end{tabular}

${ }^{\mathrm{a}} \mathrm{A}=\mathrm{a}+\mathrm{bC}$ where $\mathrm{c}$ is the concentration in $\mu \mathrm{g} \mathrm{mL}^{-1}$. ${ }^{\mathrm{b}}$ Theoretical value for $t$ and $F$ at $95 \%$ confidence level.

\section{Robustness and ruggedness}

The robustness of an analytical method refers to its capability to remain unaffected by small and deliberate variations in method parameters and provides an indication of its reliability in regular analysis. Robustness test of the proposed method was performed with deliberate small changes at volume of $0.005 \mathrm{M} \mathrm{KMnO}_{4}( \pm 0.1 \mathrm{~mL})$, volume of $0.5 \mathrm{M} \mathrm{NaOH}( \pm 0.1 \mathrm{~mL})$ and reaction time $( \pm 2.0 \mathrm{~min})$. Only one parameter was changed in the each experiment. Each deliberate small change was analyzed 5.0 independent series containing known concentration of each drug. The results (Table 7) showed good recovery (97.45-101.5\%) with low relative standard deviation $(0.58-1.36 \%)$. The results indicated that the small variations in any of the variables did not significantly affect the results. Therefore the proposed method is robust to the small changes in experimental conditions.

Ruggedness was also tested by applying the methods to the assay of the studied drugs using the same operational conditions on two different instruments at two different laboratories and different elapsed times. Results obtained from lab-to-lab and day-to-day variations were reproducible, as the $\mathrm{RSD} \leq 3.0 \%$. 
Table 6. Inter-day and intra-day accuracy and precision for the determination of GMF and MOX in bulk powders by the proposed method (fixed time).

\begin{tabular}{|c|c|c|c|c|c|}
\hline Drug & $\begin{array}{c}\text { Taken } \\
\mu \mathrm{g} \mathrm{mL}^{-1}\end{array}$ & $\begin{array}{l}\text { Found } \\
\mu \mathrm{g} \mathrm{mL}^{-1}\end{array}$ & RSD\% & RE\% & Recovery $\%^{\mathrm{a}} \pm \mathrm{SD}$ \\
\hline \multicolumn{6}{|c|}{ Inter-day } \\
\hline \multirow[t]{4}{*}{ GMF } & 4.0 & 3.95 & 0.40 & -1.25 & $98.75 \pm 0.40$ \\
\hline & 8.0 & 8.05 & 0.52 & 0.63 & $100.63 \pm 0.52$ \\
\hline & 12 & 11.96 & 0.51 & -0.33 & $99.67 \pm 0.51$ \\
\hline & 16 & 15.90 & 0.62 & -0.62 & $99.38 \pm 0.62$ \\
\hline Mean \pm SD & & & & & $99.61 \pm 0.78$ \\
\hline \multirow{4}{*}{ MOX } & 4.0 & 4.02 & 0.13 & 0.50 & $100.50 \pm 0.13$ \\
\hline & 10 & 10.08 & 0.23 & 0.80 & $100.80 \pm 0.23$ \\
\hline & 16 & 16.08 & 0.32 & 0.50 & $100.50 \pm 0.32$ \\
\hline & 22 & 21.80 & 0.41 & -0.91 & $99.09 \pm 0.41$ \\
\hline Mean \pm SD & & & & & $100.22 \pm 0.77$ \\
\hline \multirow[t]{4}{*}{ GTF } & 8.0 & 7.92 & 0.20 & -1.0 & $99.00 \pm 0.20$ \\
\hline & 16 & 16.15 & 0.33 & 0.94 & $100.94 \pm 0.33$ \\
\hline & 24 & 23.80 & 0.47 & -0.83 & $99.17 \pm 0.47$ \\
\hline & 32 & 32.25 & 0.53 & 0.78 & $100.78 \pm 0.53$ \\
\hline Mean \pm S. D & & & & & $99.97 \pm 1.03$ \\
\hline \multicolumn{6}{|c|}{ Intra-day } \\
\hline \multirow[t]{4}{*}{ GMF } & 4.0 & 4.02 & 0.37 & 0.50 & $100.50 \pm 0.37$ \\
\hline & 8.0 & 7.97 & 0.42 & -0.37 & $99.63 \pm 0.42$ \\
\hline & 12 & 12.03 & 0.60 & 0.25 & $100.25 \pm 0.60$ \\
\hline & 16 & 16.04 & 0.77 & 0.25 & $100.25 \pm 0.77$ \\
\hline Mean \pm SD & & & & & $100.18 \pm 0.37$ \\
\hline \multirow[t]{4}{*}{ MOX } & 4.0 & 3.97 & 0.30 & -0.75 & $99.25 \pm 0.30$ \\
\hline & 10 & 9.96 & 0.48 & -0.40 & $99.60 \pm 0.48$ \\
\hline & 16 & 15.92 & 0.64 & -0.50 & $99.50 \pm 0.64$ \\
\hline & 22 & 22.07 & 0.81 & 0.32 & $100.32 \pm 0.81$ \\
\hline Mean \pm SD & & & & & $99.67 \pm 0.46$ \\
\hline \multirow[t]{4}{*}{ GTF } & 8.0 & 8.02 & 0.35 & 0.25 & $100.25 \pm 0.20$ \\
\hline & 16 & 15.94 & 0.40 & -0.37 & $99.63 \pm 0.33$ \\
\hline & 24 & 24.04 & 0.59 & 0.17 & $100.17 \pm 0.47$ \\
\hline & 32 & 31.90 & 0.61 & -0.31 & $99.69 \pm 0.53$ \\
\hline Mean \pm SD & & & & & $99.94 \pm 0.32$ \\
\hline
\end{tabular}

${ }^{a}$ Average of six determinations.

\section{Applications of pharmaceutical preparations}

The proposed kinetic (fixed time) spectrophotometric methods were applied to the determination of the studied drugs in their pharmaceutical formulations. Common tablet excipients did not interfere with the analysis. In addition, the proposed method enabled the determination of GMF, MOX and GTF in their dosage forms (tablets) without any interference from the inactive ingredients clearly demonstrates the selectivity of the proposed methods.

Reference methods were adopted for the assay of the studied dosage forms. These methods include the reference spectrophotometric methods for GMF [25], MOX [33] and GTF [16] dosage forms. These results were compared with those obtained from the reference spectrophotometric methods for GMF, MOX and GTF dosage forms by statistical analysis with respect to the accuracy (by student's $t$-test) and precision (by $F$-test). No significant differences were found between the calculated and theoretical values of $t$ - and $F$-tests at $95 \%$ confidence 
level proving similar accuracy and precision in the determination of the studied drugs by the proposed and references methods Table 8 .

Table 7. Results of robustness test of the proposed method.

\begin{tabular}{|l|l|c|c|c|c|}
\hline Drug & Parameters & Taken $(\mu \mathrm{g} / \mathrm{mL})$ & Found ${ }^{\mathrm{a}} \pm \mathrm{SD}$ & Recovery $(\%)$ & $\begin{array}{c}\text { RSD } \\
(\%)\end{array}$ \\
\hline GMF & $0.005 \mathrm{M} \mathrm{KMnO}_{4}( \pm 0.1 \mathrm{~mL})$ & 20 & $19.67 \pm 0.173$ & 98.35 & 0.88 \\
\hline & $0.5 \mathrm{M} \mathrm{NaOH}( \pm 0.1 \mathrm{~mL})$ & 20 & $19.49 \pm 0.149$ & 97.45 & 0.76 \\
\hline & Reaction time $( \pm 2.0 \mathrm{~min})$ & 20 & $20.05 \pm 0.213$ & 100.25 & 1.06 \\
\hline $\begin{array}{l}\mathrm{MO} \\
\mathrm{X}\end{array}$ & $0.005 \mathrm{M} \mathrm{KMnO}( \pm 0.1 \mathrm{~mL})$ & 20 & $19.56 \pm 0.126$ & 97.90 & 0.64 \\
\hline & $0.5 \mathrm{M} \mathrm{NaOH}( \pm 0.1 \mathrm{~mL})$ & 20 & $20.14 \pm 0.258$ & 100.70 & 1.29 \\
\hline & Reaction time $( \pm 2.0 \mathrm{~min})$ & 20 & $19.75 \pm 0.114$ & 98.75 & 0.58 \\
\hline $\mathrm{GTF}$ & $0.005 \mathrm{M} \mathrm{KMnO}( \pm 0.1 \mathrm{~mL})$ & 30 & $29.25 \pm 0.373$ & 97.50 & 1.28 \\
\hline & $0.5 \mathrm{M} \mathrm{NaOH}( \pm 0.1 \mathrm{~mL})$ & 30 & $30.45 \pm 0.288$ & 101.50 & 0.95 \\
\hline & Reaction time $( \pm 2.0 \mathrm{~min})$ & 30 & $30.20 \pm 0.417$ & 100.67 & 1.36 \\
\hline
\end{tabular}

${ }^{\mathrm{a}}$ average of three determinations. $\mathrm{SD}=$ Standard deviation and RSD = Relative standard deviation.

Table 8. Application of the proposed method to the determination of the studied drugs in its pharmaceutical preparations.

\begin{tabular}{|c|c|c|c|}
\hline Sample & & Proposed method & Reported methods \\
\hline GMF & & & {$[29]$} \\
\hline \multirow[t]{3}{*}{ Factive tablets } & $\mathrm{X} \pm \mathrm{SD}^{\mathrm{a}}$ & $99.86 \pm 0.73$ & $100.08 \pm 0.56$ \\
\hline & $t$-Value $\mathrm{e}^{\mathrm{b}}$ & 0.53 & \\
\hline & $F$-Value ${ }^{\mathrm{b}}$ & 1.70 & \\
\hline \multirow[t]{3}{*}{ Flobiotic tablets } & $\mathrm{X} \pm \mathrm{SD}^{\mathrm{a}}$ & $99.70 \pm 0.50$ & $99.94 \pm 0.68$ \\
\hline & $t$-Value $\mathrm{e}^{\mathrm{b}}$ & 0.64 & \\
\hline & $F-$ Value $^{\mathrm{b}}$ & 1.85 & \\
\hline \multirow[t]{3}{*}{ GemiQue tablets } & $\mathrm{X} \pm \mathrm{SD}^{\mathrm{a}}$ & $99.50 \pm 0.61$ & $99.85 \pm 0.49$ \\
\hline & $t$-Value $\mathrm{e}^{\mathrm{b}}$ & 1.0 & \\
\hline & $F$-Value ${ }^{\text {b }}$ & 1.55 & \\
\hline MOX & & & [40] \\
\hline \multirow[t]{3}{*}{ Avelox ® tablets } & $\mathrm{X} \pm \mathrm{SD}^{\mathrm{a}}$ & $99.38 \pm 0.82$ & $99.03 \pm 0.97$ \\
\hline & $t$-Value $^{\mathrm{b}}$ & 0.62 & \\
\hline & $F-$ Value $^{\mathrm{b}}$ & 1.40 & \\
\hline \multirow[t]{3}{*}{ Moxiflox tablets } & $\mathrm{X} \pm \mathrm{SD}^{\mathrm{a}}$ & $99.65 \pm 0.41$ & $99.34 \pm 0.34$ \\
\hline & $t$-Value $\mathrm{e}^{\mathrm{b}}$ & 1.30 & \\
\hline & $F$-Value ${ }^{\mathrm{b}}$ & 1.45 & \\
\hline \multirow[t]{2}{*}{ Moxifloxacin tablets } & $\mathrm{X} \pm \mathrm{SD}^{\mathrm{a}}$ & $99.70 \pm 0.85$ & $99.94 \pm 0.92$ \\
\hline & $t$-Value ${ }^{\mathrm{b}}$ & 0.43 & \\
\hline GTF & $F-$ Value $^{\mathrm{b}}$ & 1.17 & [16] \\
\hline \multirow[t]{3}{*}{ Tequin $®$ tablets } & $\mathrm{X} \pm \mathrm{SD}^{\mathrm{a}}$ & $99.25 \pm 0.95$ & $99.72 \pm 0.78$ \\
\hline & $t$-Value $\mathrm{e}^{\mathrm{b}}$ & 0.85 & \\
\hline & $F$-Value ${ }^{\mathrm{b}}$ & 1.48 & \\
\hline \multirow[t]{3}{*}{ Floxin tablets } & $\mathrm{X} \pm \mathrm{SD}^{\mathrm{a}}$ & $99.80 \pm 0.60$ & $99.50 \pm 0.35$ \\
\hline & $t$-Value ${ }^{\mathrm{b}}$ & 0.96 & \\
\hline & $F-$ Value $^{\mathrm{b}}$ & 2.94 & \\
\hline \multirow[t]{3}{*}{ Gatiflox tablets } & $\mathrm{X} \pm \mathrm{SD}^{\mathrm{a}}$ & $100.30 \pm 1.04$ & $99.94 \pm 0.71$ \\
\hline & $t$-Value $\mathrm{e}^{\mathrm{b}}$ & 0.64 & \\
\hline & $F-$ Value $^{\mathrm{b}}$ & 2.15 & \\
\hline
\end{tabular}

Bull. Chem. Soc. Ethiop. 2013, 27(3) 
${ }^{a}$ Five independent analyses. ${ }^{\mathrm{b}}$ Theoretical values for $\mathrm{t}$ and F-values at five degree of freedom and $95 \%$ confidence limit are $(\mathrm{t}=2.776)$ and $(\mathrm{F}=6.26)$.

\section{CONCLUSION}

The proposed method is simple, accurate, precise, sensitive, rapid, low cost and relatively selective compared to the reference methods. Furthermore, the proposed method does not require elaboration of procedures, which are usually associated with chromatographic methods, nor does it use extraction or heating. Furthermore, the proposed method does not require sophisticated instrumentation and tedious procedure usually associated with reference methods. In the light of all these merits, the proposed method can be considered useful and convenient for quality control and routine determination of the studied drugs in pharmaceutical dosage forms.

\section{REFERENCES}

1. Budavari, S. (Eds.) in The Merck Index, 13th ed., Merck and Co. Inc.: Whitehouse Station, New Jersey; 2001; p 777.

2. Sean, C.S. Martindale, The Complete Drug Reference, 36th ed., Electronic Version, Pharmaceutical Press: Royal Pharmaceutical Society, London; 2009.

3. Al-Hadiya, B.M.; Khady, A.A.; Mostafa, G.A. Talanta 2010, 83, 110.

4. Rote, A.R.; Pingle, S.P. J. Chromatogr. B 2009, 877, 3719.

5. Sultana, N.; Arayne, M.S.; Akhtar, M.; Shamim, S.; Gul, S.; Khan, M.M. J. Chin. Chem. Soc. 2010, 57, 708 .

6. Salem, M.Y.; El-Guindi, N.M.; Mikael, H.K.; Abd-El-Fattah, L.E.-S. Chem. Pharm. Bull. 2006, 54, 1625.

7. Santoro, M.I.; Kassab, N.M.; Singh, A.K.; Kedor-Hackmam, E.R. J. Pharm. Biomed. Anal. 2006, 40, 179.

8. Salgado, H.R.; Lopes, C.C. J. AOAC. Int. 2006, 89, 642.

9. Sharma, M.C.; Sharma, S. Int. J. PharmTech Res., 2011, 3, 1179.

10. Faria, A.F.; de Souza, M.V.N.; de Almeida, M.V.; de Oliveira, M.A.L. Anal. Chim. Acta 2006, 579, 185.

11. Elbashir, A.A.; Saad, B.; Ali, A.S.M.; Al-Azzam, K.M.M.; Aboul-Enein, H.Y. J. Liq. Chromatogr. Rel. Tech. 2008, 31, 1465.

12. Abdel Ghani, N.T.; El-Ries, M.A.; El-Shall, M.A. Anal. Sci. 2007, 23, 1053.

13. Radi, A.-E.; Wahdan, T.; Anwar, Z.; Mostafa, H. Electroanalysis 2010, 22, 2665.

14. Radi, A.-E.; Wahdan, T.; Anwar, Z.; Mostafa, H. Drug Test. Anal. 2010, 2, 397.

15. Erk, N. Anal Bioanal Chem. 2004, 378, 1351.

16. Al-Ghannam, S.M. Spectrochim. Acta A 2008, 69, 1188.

17. Salem, H. Am. J. Appl. Sci. 2005, 2, 719.

18. Ocana, J.A.; Barragan, F.J.; Callejon, M. J. Pharm. Biomed. Anal. 2005, 37, 327.

19. Tekkeli, S.E.K.; Önal A. J. Fluoresc. 2011, 21, 1001.

20. Ulu, S.T. Spectrochim. Acta A 2009, 72, 1038.

21. Razek, T.M.A.; El-Baqary, R.I.; Ramadan, A.E. Anal. Lett. 2008, 41, 417.

22. Hajera, K. Int. J. Res. Pharm. Biomed. Sci. 2012, 3, 90.

23. Balaji, V.; Poongothai, S.; Madhavi, B.; Reddy, R.; Naidu, P.Y.; Karrunakaran, C.M.; Ilavarasan, R. Pharma Sci. Mon. 2010, 2, S132.

24. Krishna, M.V.; Sankar, D.G. E-J. Chem. 2008, 5, 493.

25. Krishna, M.V.; Sankar, D.G. E-J. Chem. 2008, 5, 515.

26. Ganapathy, S.; Raju, G.V.H.; Sankar D.G.; Naidu, P.Y. Asian J. Chem. 2009, 21, 6508. 
27. Al Shoaibi Z.Y.; Gouda A.A. Anal. Chem. 2010, 9.

28. Madhuri, D.; Chandrasekhar, K.B.; Devanna, N.; Somas, G. Rasayan J. Chem. 2010, 3, 159.

29. Patel, P.U.; Suhagia, B.N.; Patel, M.M. Indian Drugs 2005, 42, 654.

30. Motwani, S.K.; Chopra, S.; Ahmad, F.J.; Khar, R.K. Spectrochim. Acta A 2007, 68, 250.

31. Sultan, M.A. Arabian J. Chem. 2009, 2, 79.

32. Chaple, D.R.; Bhusari, K.P. Asian J. Chem. 2010, 22, 2593.

33. Abdellaziz, L.M.; Hosny, M.M. Anal. Chem. Insights 2011, 6, 67.

34. Basavaiah, K.; Anil Kumar, U.R. J. Mex. Chem. Soc. 2007, 51, 106.

35. Mali, A.; Dhavale, R.; Mohite, V.; Mahindrakar, A.; Pore, Y.; Kuchekar, B. Indian J. Pharm. Sci. 2006, 68, 386.

36. Jane, J.; Subrahmanyam, E.V.S.; Sathyanarayana, D. Asian J. Chem. 2006, 18, 3210.

37. Basavaiah, K.; Anil Kumar, U.R. Proceed. Indian National Sci. Acad. 2006, 72, 225.

38. Amin, A.S.; Gouda, A.A.; El-Sheikh, R.; Zahran, F. Spectrochim. Acta A 2007, 67, 1306.

39. Basavaiah, K.; Anil Kumar, R.U. E-J. Chem. 2007, 4, 154.

40. Basavaiah, K.; Anil Kumar, R.U.; Tharpa, K. CI CEQ 2008, 14, 185.

41. Askal, H.; Refaat, I.; Darwish, I.; Marzouq, M. Chem. Pharm. Bull. 2007, 55, 1551.

42. Gouda, A.A.; El-Sheikh, R.; Amin, AS. Chem. Pharm. Bull. 2008, 56, 34.

43. Darwish, I.A.; Sultan, M.A.; Al-Arfaj, H.A. Spectrochim. Acta A 2010, 75, 334.

44. Sebaiy, M.M.; El-Shanawany, A.A.; El-Adl, S.M.; Abdel-Aziz, L.M. Asian J. Pharm. Tech. 2011, 1, 130.

45. Gouda A.A.; Arabian J. Chem. 2010, 3, 33.

46. Espinosa-Mansilla, A.; Accdovalenzuela, M.I.; Salinas, F. Canada. F. Anal. Chim. Acta 1998, 376, 193.

47. Job, P. Anal. Chem., 1939, 9133.

48. Rose, J. Advanced Physicochemical Experiments, Pitman: London; 1964; p 67.

49. Martin, N; Swarbrick, J; Cammarata, A. Physical pharmacy. 3rd ed., Lee and Febiger: Philadelphia, USA; 1969; p 344.

50. Pérez-Bendito, D.; Silva, M. Kinetic Methods in Analytical Chemistry; John Wiley and Sons: New York; 1988; $\mathrm{p} 40$.

51. Miller, J.N.; Miller, J.C.; Statistics and Chemometrics for Analytical Chemistry, $5^{\text {th }}$ ed., Pearson Prentice Hall: New York; 2005; p 202.

52. International Conference on Harmonization of Technical Requirements for Registration of Pharmaceuticals for Human Use, ICH Harmonized Tripartite Guideline, Validation of Analytical Procedures: Text and Methodology, Q2(R1), Complementary Guideline on Methodology dated 06 November 1996, ICH, London, 2005. 